\title{
The Relationship Between Depression and Cognitive Deterioration in Elderly Persons
}

\author{
José Antonio Camacho-Conde ${ }^{1, *}$ (1) \& José Manuel Galán-López² (1) \\ ${ }^{1}$ Catholic University of Avila, Avila, Spain \\ ${ }^{2}$ University Hospital of Ceuta, Ceuta, Spain
}

\begin{abstract}
The objective of this research is to describe the relationship between depressive disorder and cognitive deterioration in residentialized elderly people. This is a descriptive and correlational study with 70 elderly. The variables have been assessed with a Psychosocial Variables Questionnaire, CAMCOG and GDS. Depression was significantly correlated with cognitive level in the non-assisted elderly sample $(\mathrm{r}=0.471, \mathrm{p}=0.004)$. Participants' age is negatively associated with the score obtained in the CAMCOG of non-assisted sample $(\mathrm{r}=-0.352, \mathrm{p}=0.038)$. Depression is more frequent in institutions that care for older people when they are more dependent.
\end{abstract}

KEYWORDS: depression, cognitive decline, prevalence, psychosocial factors, cross-sectional study

\section{La Relación Entre Depresión y Deterioro Cognitivo en Personas Mayores Institucionalizadas en Residencias Españolas}

\begin{abstract}
RESUMEN - El objetivo del presente trabajo es determinar la relación entre el trastorno depresivo y el deterioro cognitivo en una población mayor institucionalizada. Se ha realizado un estudio descriptivo y correlacional con 70 mayores españoles. Para la medida de las variables se ha usado un Cuestionario de Variables Psicosociales propio, el CAMCOG del CAMDEX y la GDS. La depresión se correlaciona significativamente con el nivel cognitivo en la muestra de mayores no dependientes $(\mathrm{r}=-0.471 ; p=0.004)$. La edad se asocia elocuentemente y de forma inversa con la puntuación obtenida en el CAMCOG en la muestra de dependientes $(\mathrm{r}=-0.352 ; p=-0.038)$. La depresión está vinculada a las instituciones que atienden a mayores cuando éstos son más dependientes.
\end{abstract}

PALABRAS CLAVE: depresión, déficit cognitivo, prevalencia, factores psicosociales, estudio transversal

\section{A Relação Entre Depressão e Comprometimento Cognitivo em Idosos Institucionalizados}

\begin{abstract}
RESUMO - O objetivo deste trabalho é determinar a relação entre transtorno depressivo e comprometimento cognitivo na população idosa institucionalizada. Foi realizado um estudo descritivo e correlacional com 70 idosos espanhóis. Para a medição das variáveis, foi utilizado um Questionário de Variáveis Psicossociais, o CAMCOG do CAMDEX e GDS. A depressão se correlaciona significativamente com o nível cognitivo na maioria dos adultos não dependentes $(\mathrm{r}=-0,471$; $p=0.004)$. A idade está significativamente associada e inversamente para a pontuação obtido no CAMCOG na faixa dependente $(\mathrm{r}=-0,352 ; p=-0,038)$. A depressão está ligada às instituições que atendem prefeitos quando são muito dependentes.
\end{abstract}

PALAVRAS-CHAVES: depressão, déficit cognitivo, prevalência, fatores psicossociais, estudo transversal

\footnotetext{
*E-mail: jantonio.camacho@ucavila.es

- Submetido: 09/01/2020; Revisado: 07/04/2020; Aceito: 09/04/2020.
} 
In the last three decades, the relationship between depression and cognition in geriatric patients has been a popular topic among researchers and clinicians (Alexopoulos, 2005; Sanches, 1999; Burhanullah et al., 2020; Dickinson, Potter et al., 2011; Lichtenberg et al., 1995; Wilson et al., 2002). Despite the increase in research, significant questions remain unanswered in the cognition-affect relationship. Clinical and epidemiological research has focused on the identification of risk factors that could be modified in predementia syndromes, at a preclinical and early clinical stage of dementia disorders, with specific attention to the role of depression (Panza et al., 2010).

Research in multiple disciplines has been conducted to determine the relationship between depression and cognition, including neuropsychology, gerontology, psychiatry, and neurobiology. Most studies are crosssectional (Lichtenberg et al., 1995; McDermott \& Ebmeier, 2009; Rabbitt et al., 1994; Sakurai \& Okubo, 2020) and are based on samples of patients with dementia, either with or without depressive disorders (Diniz et al., 2013; Johansson et al., 2020). A recent longitudinal study has shown that neuropsychiatric symptoms - including depression - are risk factors or clinical indicators of preclinical dementia syndrome (Burhanullah, et al., 2020) and that depressive symptoms can be predictors of visual memory deficits in middle age (Taivalantti et al., 2020).

Longitudinal studies examining depression over time provided a variety of findings associated with reducing depression treatment (Tarugu et al., 2019), oscillating between no effect and the complete change of cognitive deficits (Lichtenberg et al., 1995).

Some of the drawbacks of studies that have found memory deficits associated with depression are due to the fact that they have been performed in patients with severe depression compared to normal controls, and using tests that require a great effort of memory and that depend on the patient's motivation (Austin mui., 2001).

Longitudinal studies provide data that can be used to determine whether older people who are depressed have a higher risk of cognitive impairment than those who are not depressed. Although longitudinal population studies are scarce (Burhanullah et al., 2020; Modrego \& Ferrández, 2004), in Europe, we can find the studies of Zunzunegui et al. (1999) and Paterniti et al. (2002) and more recently, in North America, the study of Ezzati et al. (2019) who have considered depression a predictive factor of cognitive impairment in older persons.

Cross-sectional studies on depressive symptomatology in Spanish older persons (Cerdá et al., 1997; Zunzunegui et al.,
1998) consistently estimate a prevalence two or three times higher than in other European populations, despite using different measuring instruments. On the contrary, Spanish studies on the prevalence of moderate-severe cognitive deficits obtain similar prevalence to those of other countries: between $6 \%$ and $14 \%$ of the population over 65 years old (Baladón et al., 2015; Olivera et al., 2008).

Depression is one of the most frequent problems among Spanish older people (Díaz, 2018), as revealed by the different epidemiological studies on the prevalence of depression in older people, with rates ranging from $5 \%$ to $20 \%$ in the community population, numbers that can double or triple among the institutionalized older adult population (Camacho-Conde, 2009). Depressive disorders in residential centers for the older persons are a frequent problem, but are underdiagnosed and under-treated, with a consequent decrease in quality of life. Its high recurrence rate, and the lack of proper recognition and treatment, contribute to greater morbidity and mortality, being a frequent cause of suicide (Jassim et al,, 2019; Li, 2020; Péquignot et al., 2019; Prakash, 2019).

On the other hand, institutionalization in residences is associated with factors that can favor the appearance of depressive symptoms and can increase the prevalence of this problem. This is combined with the comorbidity of diseases and decreased health in the older persons (Landi et al., 2004) which is also associated with the onset of depression, especially disorders related to the deficiency of some sense (Camacho-Conde, 2009; Cosh et al, 2019; Chou \& Chi, 2004; Kim et al,, 2011; Singh \& Lee, 2019; Wu et al., 2017) or urinary incontinence (Boi et al., 2012). Also, hearing loss increases the risk of neurocognitive impairment (Loughrey et al, 2020). Finally, it should be noted that lateonset depression has a lower hereditary component and is more influenced by social, familiar, and vital environment (Murphy, 1986).

The objective of this paper is to show the relationship between depressive symptomatology and cognitive impairment in a population of institutionalised older persons. The institutionalised older persons have been chosen as the focus of study for three reasons: (i) research has consistently shown that the prevalence of depression in older persons is two or three times higher than older people living in the community; (ii) depression in institutionalised seniors is often not as severe as in psychiatric patients, and similarly, antidepressants are less likely to be used; (iii) the assessment of depression and cognition in the institutionalised population is useful and has clinical applicability for gerontology professionals. 


\section{METHOD}

\section{Participants}

The sample was made up of 70 older persons of Spanish nationality. The non-dependent group was $60 \%$ female and $40 \%$ male (aged 63 to 99 years old, $\mathrm{M}=78.51, \mathrm{SD}=6.69$ ) and the dependent group was $54.29 \%$ female (aged 67 to 99 years old, $\mathrm{M}=82.63, \mathrm{SD}=6.60$ ). All participants were recruited from two residential institutions for older persons in the province of Jaen. The length of institutionalization was longer in the older dependents $(\mathrm{M}=4.65$ years, $\mathrm{SD}=56.53$ months) versus the older non-dependent ( $\mathrm{M}=4.75$ years, $\mathrm{SD}=57.82$ months). The average widowhood times of the non-dependent and dependent groups were 12.69 years $(\mathrm{n}=19)$ and 8.47 years $(\mathrm{n}=17)$, respectively.

In order to counteract the strange effects of psychiatric variables and facilitate the administration of tests and the validity of the results, residents with the following pathologies were not included: epileptic disorders, schizophrenia, unspecified psychotic disorders, mental retardation to varying degrees, aphasia, and severe dementia. Older persons with mild hearing loss and mild vision disorders were not excluded, since they do not interfere with the reliability of the tests. Two participants were unable to complete the entire evaluation because of severe dementia, and their data were excluded from the study.

The sociodemographic variables (gender, age, educational level, socioeconomic level, origin, and marital status) were collected through the center's database, all made under the guidelines dictated by Organic Law 15/1999, of December 13, Protection of Personal Data, and controlled by randomization. The most relevant variables are shown in Table 1.

\section{Measuring Instruments}

The scales used to assess depression and cognitive impairment were the Geriatric Depression Scale (GDS) (Yesavage et al., 1982) and the Cambridge Cognitive Test (CAMCOG) subscale of the Cambridge Examination for Mental Disorders in the Elderly (CAMDEX) (Llinás et al., 1991).

Validity and Reliability of the Scales

CAMCOG subscale (Llinás et al., 1991) of CAMDEX Interview is a cognitive battery that objectively evaluates a wide range of superior functions: orientation, language,

Table 1

Affiliation Data of Institutionalized Elders

\begin{tabular}{|c|c|c|c|c|}
\hline \multirow{2}{*}{ Indicators } & \multicolumn{2}{|c|}{ Non-dependents } & \multicolumn{2}{|c|}{ Dependents } \\
\hline & $\mathbf{N}$ & $\%$ & $\mathbf{n}$ & $\%$ \\
\hline \multicolumn{5}{|c|}{ Voluntarity level upon admission } \\
\hline Voluntary income & 27 & 77.14 & 22 & 62.86 \\
\hline Involuntary income & 8 & 22.86 & 13 & 37.14 \\
\hline \multicolumn{5}{|c|}{ Marital status prior to admission } \\
\hline Widower & 14 & 40 & 22 & 62.86 \\
\hline Married & 12 & 34.28 & 3 & 8.56 \\
\hline Separated/Divorced & 3 & 8.57 & 9 & 25.72 \\
\hline Single & 6 & 17.14 & 1 & 2.86 \\
\hline \multicolumn{5}{|l|}{ Current Marital Status } \\
\hline Widower & 27 & 77.15 & 24 & 68.57 \\
\hline Married & 4 & 11.43 & 1 & 2.86 \\
\hline Separated/Divorced & 2 & 5.71 & 9 & 25.72 \\
\hline Single & 2 & 5.71 & 1 & 2.86 \\
\hline \multicolumn{5}{|c|}{ Residence before admission } \\
\hline Institution & 3 & 8.57 & 2 & 5.71 \\
\hline Sons & 4 & 11.42 & 5 & 14.28 \\
\hline Spouse & 6 & 17.14 & 11 & 31.42 \\
\hline Alone & 15 & 42.85 & 13 & 37.14 \\
\hline Other family & 6 & 17.14 & 4 & 11.24 \\
\hline Others & 1 & 2.86 & - & - \\
\hline
\end{tabular}


memory, praxis, attention, abstract thinking, perception, and calculation. This scale consists of 60 items (63 in the Spanish version) and includes all of the Mini-Mental State Examination (MMSE) (Folstein et al., 1975), and in the Spanish version, three others have been added to include the Spanish adaptation of the Cognitive Miniexamen (MEC) (Lobo et al., 1979).

GDS is the only self-report insturment built specifically for the assessment of depression in older persons. It is composed of 30 items, somatic items excluded. This way, a problem present in most self-report instruments - the confusion of depressive symptoms with the common physical symptoms in the older persons - was avoided (Gallagher \& Thompson, 1983). If the cut-off point is set to 11 , a sensitivity of 0.84 and a specificity of 0.95 is obtained (Izal \& Montorio, 1993; Rodríguez, 1998). Applying a cutoff point of 14 gives a sensitivity of 0.80 and a specificity of 1 (Yesavage et al., 1982).

\section{PROCEDURES}

The Ethics Committee of the Equality and Social Welfare Council of Andalusian Government (Spain) approved the study. The study was carried out in accordance with the Code of Ethics of the World Medical Association (Declaration of Helsinki) for human experiments. The study was administered in five phases. A first in which a clinical review was carried out through the psychological, medical and social history. In the second phase, the evolutionary stage and the existing diagnoses of cognitive impairment and dementia are evaluated. The third phase was aimed at detecting the onset of depressive symptoms, if it is before admission, before or after deterioration. The fourth phase was devoted to accounting for the number of older persons with depression and/or cognitive impairment, assessed using GDS screening (Yesavage et al., 1982) and CAMCOG subscale of CAMDEX (Llinás et al., 1991). In the fifth phase, a comparative study of the normal and impaired elderly and the associated psychosocial variables was carried out.

The collection of psychological, medical, and social data was carried out through a cross-sectional investigation in the two residences, following the protocol above and measured by the study's psychologist.
Cognitive function was measured by CAMCOG, and depressive symptomatology was assessed by GDS (both Spanish adaptations) (Llinás et al., 1991; Snowdon, 1990). The psychological data concerning cognitive and affective evolution were offered by the psychologist of the centers. The sociodemographic data were mostly extracted through the Psychosocial Variables Questionnaire of the author, corroborated and complemented with the social file of social workers. The clinical data were provided by the doctors at each center. In order to avoid the twilight effect after lunch in the gerontological population, the tests were applied in the morning period.

\section{Statistic Analysis}

Statistical analysis were done using the statistical program IBM SPSS Statistics V25.0 for Windows, and presented as descriptive and correlational statistics (sample size, percentage, and Pearson's correlation). Besides, $p$-values $<0.05$ were considered statistically significant.

\section{RESULTS}

When applying the Pearson test, we observed no interaction between age and the GDS of the non-dependent older persons ( $\mathrm{n}=35, \mathrm{r}=0.142, p=0.415)$, nor with cognitive impairment $(\mathrm{r}=-0.234, \mathrm{p}=0.177)$.

We detected no significant relationship between age and GDS score in the sample of dependents $(\mathrm{n}=35, \mathrm{r}=0.133$, $p=0.447$ ), but there was a significant inverse relationship with CAMCOG score $(\mathrm{r}=0.352 ; \mathrm{p}=0.038)$; CAMCOG score tends to decrease (indicating greater cognitive impairment) with advancing age.

No association was observed between institutionalization time and the score obtained on the cognitive and affective scales (GDS and CAMCOG) in both groups (GDS-nondependent: $\mathrm{r}=-0.209, p=0.234$. CAMCOG-non-dependent: $\mathrm{r}=0.007, p=0.967$ ); (GDS-dependent: $\mathrm{r}=0.251, p=0.152$. CAMCOG-dependent: $\mathrm{r}=-0.021, p=0.907$ ).
According to the psychological state of the nondependent elderly at the time of admission, it was observed that - with an average prior evaluation $>2$ years- a sample of 18 non-dependent elderly through clinical interview, GDS and MEC or TIMC, presented depression without deterioration $33.33 \%(\mathrm{n}=6)$, depression with deterioration $5.55 \%(\mathrm{n}=1)$, and without depression and without deterioration $61.11 \%(n=11)$. Among the six who had depressive symptoms without cognitive impairment, it was subsequently found that four of them presented cognitive impairment. Among the 11 that presented neither depression nor cognitive impairment, here we found that $27.27 \%(n=3)$ presented cognitive impairment and depression together.

Functional capacity was analyzed through activities of basic and instrumental Activities of Daily Living (ADLs). The results obtained in both are shown together (normal 
non-dependent versus impaired non-dependent), and specify the sample size and the percentage - Without Help (WH), With Difficulty (WD), Needs Help (NH), and Unable (U) (Tables 2 and 3).

On the other hand, there was no significant relationship between the functional capacity in ABVD and the score obtained in the GDS of the non-dependent $(\mathrm{r}=0.159$, $p=0.361$ ). There is a direct correlation between the functional capacity in basic ADLs and the score obtained in the CAMCOG of the non-dependent group $(\mathrm{r}=0.463, p=0.005)$, which means that the higher the functional capacity score in the basic ADLs, the higher the CAMCOG score. According to the above, the functional capacity in these types of activities results in a better cognitive level, and vice versa.
There were no significant relationships between functional capacity in ABVD in dependents and the scores obtained using GDS ( $\mathrm{r}=-0.109, p=0.532)$ and CAMCOG $(\mathrm{r}=0.089$, $p=0.611)$.

No significant relationship was found between the functional capacity in AIVD and the resulting scores in GDS ( $\mathrm{r}=-0.312, p=0.068)$, but a significant relationship was found between the functional capacity in AIVD and the resulting score of the CAMCOG $(\mathrm{r}=0.682, p=0.000)$ in the sample of non-dependents. The latter indicates that the existing direct relationship expresses a better cognitive capacity when greater functional capacity is preserved in these activities, and a better cognitive level facilitates the development of these activities.

Table 2

Basic Activities of the Daily Life of the Non-Dependent Elderly According to Degree of Autonomy

\begin{tabular}{|c|c|c|c|c|}
\hline \multirow{2}{*}{ Indicators } & \multicolumn{2}{|c|}{ Autonomous } & \multicolumn{2}{|c|}{ Some physical impairment } \\
\hline & $\mathbf{n}$ & $\%$ & $\mathbf{n}$ & $\%$ \\
\hline \multicolumn{5}{|c|}{ Getting up/ Laying down } \\
\hline Without help & 16 & 100 & 18 & 94.7 \\
\hline With difficulty & - & - & - & - \\
\hline Need help & - & - & 1 & 5.26 \\
\hline \multicolumn{5}{|l|}{ Dressing/Undressing } \\
\hline Without help & 16 & 100 & 18 & 94.7 \\
\hline With difficulty & - & - & - & - \\
\hline Need help & - & - & 1 & 5.26 \\
\hline \multicolumn{5}{|l|}{ Cleanliness } \\
\hline Without help & 16 & 100 & 18 & 94.7 \\
\hline With difficulty & - & - & - & - \\
\hline Need help & - & - & 1 & 5.26 \\
\hline \multicolumn{5}{|l|}{ Bath/Shower } \\
\hline Without help & 16 & 100 & 15 & 78.94 \\
\hline With difficulty & - & - & 2 & 10.52 \\
\hline Need help & - & - & 2 & 10.52 \\
\hline \multicolumn{5}{|l|}{ WC use } \\
\hline Without help & 16 & 100 & 17 & 89.47 \\
\hline With difficulty & - & - & 2 & 10.52 \\
\hline Need help & - & - & - & - \\
\hline \multicolumn{5}{|l|}{ Up/down stairs } \\
\hline Without help & 14 & 87.50 & 13 & 64.82 \\
\hline With difficulty & 2 & 12.50 & 5 & 26.30 \\
\hline Need help & - & - & 1 & 5.26 \\
\hline \multicolumn{5}{|l|}{ Walking and strolling } \\
\hline Without help & 14 & 87.50 & 12 & 63.15 \\
\hline With difficulty & 2 & 12.50 & 6 & 31.57 \\
\hline Need help & - & - & 1 & 5.26 \\
\hline \multicolumn{5}{|l|}{ Eating } \\
\hline Without help & 16 & 100 & 17 & 89.47 \\
\hline With difficulty & - & - & - & - \\
\hline Need help & - & - & 2 & 10.52 \\
\hline
\end{tabular}


Instrumental Activities of the Daily Life Of The Dependent Elderly by Degree of Autonomy

\begin{tabular}{|c|c|c|c|c|}
\hline \multirow{2}{*}{ Indicators } & \multicolumn{2}{|c|}{ Autonomous } & \multicolumn{2}{|c|}{ Some physical impairment } \\
\hline & $\mathbf{n}$ & $\%$ & $\mathbf{n}$ & $\%$ \\
\hline \multicolumn{5}{|l|}{ To read } \\
\hline Without help & 13 & 81.25 & 11 & 57.80 \\
\hline With difficulty & 1 & 6.25 & 3 & 15.78 \\
\hline Need help & 2 & 12.50 & 5 & 26.32 \\
\hline \multicolumn{5}{|l|}{ To write } \\
\hline Without help & 11 & 68.75 & 11 & 57.80 \\
\hline With difficulty & 4 & 25.00 & 3 & 15.78 \\
\hline Need help & 2 & 5.26 & 5 & 26.32 \\
\hline \multicolumn{5}{|l|}{ To use the phone } \\
\hline Without help & 15 & 93.75 & 17 & 89.47 \\
\hline With difficulty & - & - & - & - \\
\hline Need help & 1 & 5.26 & 2 & 10.53 \\
\hline \multicolumn{5}{|l|}{ To shop } \\
\hline Without help & 16 & 100 & 9 & 47.36 \\
\hline With difficulty & - & - & 1 & 5.26 \\
\hline Need help & - & - & 9 & 47.36 \\
\hline \multicolumn{5}{|l|}{ To use medication } \\
\hline Without help & 16 & 100 & 12 & 63.16 \\
\hline With difficulty & - & - & 1 & 5.26 \\
\hline Need help & - & - & 6 & 31.58 \\
\hline \multicolumn{5}{|c|}{ To use public transports } \\
\hline Without help & 15 & 93.75 & 9 & 47.36 \\
\hline With difficulty & - & 5.26 & 1 & 5.26 \\
\hline Need help & - & - & 9 & 47.36 \\
\hline \multicolumn{5}{|l|}{ To handle money } \\
\hline Without help & 14 & 87.50 & 15 & 78.95 \\
\hline With difficulty & 2 & 12.50 & 1 & 5.26 \\
\hline Need help & - & - & 3 & 15.79 \\
\hline \multicolumn{5}{|l|}{ To visit the doctor } \\
\hline Without help & 14 & 87.50 & 16 & 84.21 \\
\hline With difficulty & 2 & 12.50 & - & - \\
\hline Need help & - & - & 3 & 15.79 \\
\hline \multicolumn{5}{|l|}{ To trim your toenails } \\
\hline Without help & 11 & 68.75 & 6 & 31.58 \\
\hline With difficulty & 4 & 25 & 2 & 10.53 \\
\hline Need help & 1 & 6.25 & 11 & 57.89 \\
\hline
\end{tabular}

This conjunction is also presented in the sample of dependents: that is, the relationship between the functional capacity in AIVD and CAMCOG score is significant $(\mathrm{r}=0.631, p=0.000)$, but this relationship is not significant when using GDS score $(-0.144, p=0.409)$.

The comorbidity associated with depression in nondependent older persons was $45.71 \%$, compared to $74.28 \%$ in dependent older persons. The most representative pathologies in both groups were: hypertension (HT) in $40 \%$, diabetes in $22.86 \%$, hip fractures in $20 \%$, depression in $17.14 \%$, Chronic Obstructive Pulmonary Disease (COPD) in $17.14 \%$, stroke in $11.43 \%$, heart disease in $8.57 \%$, Alzheimer's disease in $8.57 \%$, Parkinson's disease in $8.57 \%$, vertiginous syndrome in $8.57 \%$, mild hearing loss in $8.57 \%$, varicose syndrome in $5.71 \%$, and headaches and/ or migraines in $5.71 \%$.

In the analysis of the drugs associated with depression, we found that $26.66 \%$ of a sub-sample of non-dependents 
$(\mathrm{n}=15)$ take medication with possible depressive action, and among these, $100 \%$ have depression. Among the subsample of dependents, $53.33 \%$ are prescribed medication with possible depressive action, and also $100 \%$ of these have depression.

In an approach to the study of the evolutionary history of depression and cognitive impairment in non-dependent elderly evaluated jointly - with a temporal mean $>$ two years prior to this study - with GDS-30 and MEC, they had a score in GDS-30 $(\mathrm{M}=30 \mathrm{SD}=5.12 \mathrm{n}=12)$ and in MEC $(\mathrm{M}=30 \mathrm{SD}=3.26 \mathrm{n}=10)$. In the elderly dependents - with an evaluation average $>2$ years - they scored in GDS-30 $(\mathrm{M}=9.42 \mathrm{SD}=2.82 \mathrm{n}=7)$. The differential mean is significantly higher in GDS over time, that is, both the non-dependent and the dependent show higher mean scores on this scale as specified below, observing a differential mean in the GDS-non-dependent of $>3.18$ points and in the GDS-dependent $>6.29$.

The prevalence of depression in non-dependent older persons was $57.14 \%$, compared to $82.85 \%$ in dependent older persons. The mean age of those with depression was 79.55 years among non-dependents $(n=20)$ and 82.72 years among dependents $(\mathrm{n}=7)$. In the non-dependent older persons, $72.22 \%(n=13)$ of the women and $41.18 \%(n=7)$ of the men were depressed. In the dependent older persons, $89.47 \%(n=17)$ of women and $75 \%$ of men were depressed.

The mean scores obtained in CAMCOG were 66.80 $(\mathrm{SD}=14.25)$ for the sample of non-dependent older persons, and $34.62(\mathrm{SD}=16.18)$ for dependent older persons. In the non-dependent older persons, the mean GDS score was $11.60(\mathrm{SD}=6.00)$, compared to $16.94(\mathrm{SD}=6.05)$ among dependent older persons. The mean scores in the CAMCOG were $77.66(\mathrm{SD}=4.90)$ for the sample of non-dependent and non-impaired older persons, and were $55.35(\mathrm{SD}=11.63)$ in the sample of non-dependent and impaired older persons. The average GDS scores were: non-dependent, non-depressed $(\mathrm{M}=5.93, \mathrm{SD}=2.52)$; nondependent, depressed $(\mathrm{M}=15.85, \mathrm{SD}=3.94)$; dependent, non-depressed $(\mathrm{M}=7.16, \mathrm{SD}=1.47)$; and dependent, depressed $(\mathrm{M}=18.96, \mathrm{SD}=4.40)$.

We found that among non-dependents who scored CAMCOG $\leq 69,94.11 \%$ (16/17) had depression; with a CAMCOG $<58,100 \%(7 / 7)$ had depression. In the group of dependents with a CAMCOG $\leq 69,82.85 \%(29 / 35)$ had depression; among those scoring CAMCOG $<58,87.10 \%$ $(27 / 31)$ had depression; among those scoring CAMCOG $<$ $45,88.46 \%$ (23/26) had depression; and among those scoring CAMCOG $\leq 30(17 / 17), 100 \%$ had depression.

In both groups, we observed an increase in cognitive impairment as GDS score increased. In the non-dependent group, when GDS is $\leq 11,78.95 \%(15 / 17)$ had cognitive impairment; when GDS is $\geq 14,85.71 \%(12 / 14)$ had cognitive impairment; and with a score $<20,100 \%(3 / 3)$ had cognitive impairment. In contrast, this difference disappears in the group of dependents, in which, from a score of $\geq 11$, $100 \%$ had cognitive impairment.

In the non-dependent residents, the degrees of deterioration in the two groups non-deterioration (ND), minimum, mild, moderate, or severe were: ND, $51.42 \%$ $(\mathrm{n}=18)$; minimum, 2.86\% $(\mathrm{n}=1)$; slight, $22.86 \%(\mathrm{n}=8)$; moderate, $17.14 \%(n=6)$; and severe, $5.71 \%(n=2)$. Conversely, those dependent residents showed a higher percentage of deterioration in the higher-grade criteria: no residents with ND and minimal deterioration, $11.43 \%$ $(\mathrm{n}=4)$ with slight, $22.86 \%(\mathrm{n}=8)$ with moderate, and $65 \%$ with severe $(n=23)$.

When comparing the GDS and CAMCOG scores of non-dependent older persons, we detected a significant relationship (Pearson's correlation test, $\mathrm{r}=-0.471, p=0.004$ ). We detected no such CAMCOG-GDS relationship for the dependent older persons (Pearson's correlation test, $\mathrm{r}=0.156, p=0.372$ ). The student's $t$-test was applied in the two independent samples, obtaining a bilateral significance of 0.005 , so that the null hypothesis is rejected. This indicates that there is a likely relationship between depression, cognitive impairment, and the development of dementia.

\section{DISCUSSION}

Our results indicate that depressive symptomatology correlates with cognitive impairment, and through a retrospective analysis, in a subsample, we detected considerably impaired development in one in every three older persons. This finding is consistent with longitudinal studies of large samples that predict the incidence of dementia (Ezzati et al., 2019; Tan et al., 2019). Our findings are in line with other studies (Garay, 2007; Plati et al. , 2006). Recent studies have shown that over time depression predicts cognitive impairment (Chan et al., 2019; Dean, Oulhaj, Zamboni, Dejager, \& Wilcock, 2014) and Alzheimer's disease (Javaherian et al., 2019; Ruthirakuhan et al., 2019).
Our findings indicate high rates of depressive symptoms in institutionalized elderly people. The prevalence of depressive disorder evidenced in the present work is high and similar to that noted in other studies (Beekman et al., 2000; Izal \& Montorio, 1993; Schoevers et al., 2003; Snowdon, 1990) and depressive disorder was more common in the dependent group of elderly. These findings are consistent with other studies that have reported an incidence of depression four times higher among institutionalized older people than noninstitutionalized older people (Valvanne et al., 1996).

There are significant differences in the basic and instrumental ADLs between non-depressed and depressed 
non-dependents, and between non-depressed and depressed dependents. Both depressive symptomatology and cognitive impairment are related to a greater deficit in executive functions (Plati et al., 2006). The basic and instrumental functional capacity is significantly related to the cognitive level of the non-dependent group, and the advanced functional disability situation in the dependent group correlates with the cognitive level of impairment, since the degree of limitation and dependence of the dependents is higher (Ames, 1991; Harrison et al., 1990).

Depression is a frequent symptom in neurodegenerative diseases (Alzheimer's, Parkinson's, dementia with Lewy bodies, frontotemporal and cerebrovascular dementia), both from the initial and more advanced stages of the disease, which may accompany cognitive symptoms (CamachoConde, 2009, 2019; Diniz et al., 2013; Johansson et al., 2020; Ray \& Agarwal, 2020).

The progressive aging of the population, and the increased risk of depression in recent generations, mean that in the future the frequency of depression in older persons will be even greater, and will become a public and/or mental health problem of great relevance. Given this health problem, the availability of early detection instruments is necessary (Plati et al., 2006) as well as to initiate an early therapeutic intervention in residential institutions by gerontology professionals (Plati et al., 2006) in the same way that it has been carried out from the centers of social or health care (Won \& Kim, 2019).

Also, due to the gradual ageing of the population and the increase in the institutionalization of the elderly, further research should be carried out to assess how it affects traditional models compared to other more innovative models (Leung et al., 2020). The relationships between depressive symptoms and institutionalisation should be further investigated, since in our study it was not possible to determine whether institutionalisation alone favours depression, or if there is a greater number of depressed older people institutionalised by their families. The same relationship can be considered when thinking about cognitive impairment and institutionalisation (Plati et al., 2006).

Finally, it is important to consider that depressive symptoms might be an early manifestation rather than a risk factor for dementia and Alzheimer's disease, arguing that the underlying neuropathological condition that causes cognitive impairment or dementia also causes depressive symptoms. In this scenario, at least in certain subsets of older patients, end-of-life depression, Mild Cognitive Impairment (MCI), and dementia could represent a possible clinical continuum (Panza et al., 2010).

\section{CONCLUSION}

In our study, the presence of a high prevalence of depression coincides with other studies conducted in the institutionalized gerontological population (Almomani \& Bani-Issa, 2017; Selbæk et al., 2013). Depressive symptomatology has not been able to be associated with functional capacity in either group, but it has been proven in longitudinal studies. However, it remains unclear whether there is a significant relationship between basic and instrumental functional capacity at the cognitive level of the non-dependent group with the cognitive level of impairment (Banaszak-Holl et al., 2011; Bürge et al., 2013; Jerez-Roig et al., 2017). Non-dependent elderly patients who are admissioned to institutions with depression seem to have a greater tendency to develop cognitive impairment and dementia than those who enter without depressive symptoms (Zunzunegui, et al., 1999).

The generalizability of the study is limited by the small number of elderly in the sample. We do not attempt to make exhaustive conclusions, and this work should stimulate future more extensive and longitudinal cross-sectional research with a national scope. The findings are extrapolated to older persons who are able to complete cognitive tests and answer the GDS questions.

\section{REFERENCES}

Alexopoulos, G. S. (2005). Depression in the Elderly. The Lancet, 365(9475), 1961-1970. https://doi.org/10.1016/S01406736(05)66665-2

Almomani, F. M., \& Bani-Issa, W. (2017). The Incidence of Depression among Residents of Assisted Living: Prevalence and Related Risk Factors. Clinical Intervention in Aging, 12, 1645-1653. https://doi.org/10.2147/CIA.S147436

Ames, D. (1991). Epidemiological Studies of Depression Among The Elderly in Residential and Nursing Homes. International Journal of Geriatric Psychiatry, 6(6), 347-354. https://doi. org/10.1002/gps.930060604

Austin, M.-P., Mitchell, P., \& Goodwin, G. M. (2001). Cognitive Deficits in Depression: Possible Implications for Functional Neuropathology. The British Journal of Psychiatry, 178(3), 200-206. https://doi.org/10.1192/bjp.178.3.200
Baladón, L., Fernández, A., Rubio-Valera, M., Cuevas-Esteban, J., Palao, D. J., Bellon, J. A., \& Serrano-Blanco, A. (2015). Prevalence of Mental Disorders in Non-Demented Elderly People in Primary Care. International Psychogeriatrics, 27(5), 757-768. https://doi.org/10.1017/S1041610215000575

Banaszak-Holl, J., Liang, J., Quinones, A., Cigolle, C., Lee, I.-C., \& Verbrugge, L. M. (2011). Trajectories of Functional Change Among Long Stayers in Nursing Homes: Does Baseline Impairment Matter? Journal of Aging and Health, 23(5), 862882. https://doi.org/10.1177/0898264311399759

Beekman, A. T., de Beurs, E., van Balkom, A. J., Deeg, D. J., van Dyck, R., \& van Tilburg, W. (2000). Anxiety and Depression in Later Life: Co-Occurrence and Communality of Risk Factors. American Journal of Psychiatry, 157(1), 89-95. https://doi. org/10.1176/ajp.157.1.89 
Boi, R., Racca, L., Cavallero, A., Carpaneto, V., Racca, M., Dall'Acqua, F., Richetti, M., Alida, S., \& Odetti, P. (2012). Hearing Loss and Depressive Symptoms in Elderly Patients. Geriatrics \& Gerontology International, 12(3), 440-445. https://doi.org/10.1111/j.1447-0594.2011.00789.x

Bürge, E., von Gunten, A., \& Berchtold, A. (2013). Factors Favoring a Degradation or An Improvement in Activities of Daily Living (ADL) Performance Among Nursing Home (NH) Residents: A Survival Analysis. Archives of Gerontology and Geriatrics, 56(1), 250-257. https://doi.org/10.1016/j.archger.2012.09.001

Burhanullah, M. H., Tschanz, J. T., Peters, M. E., Leoutsakos, J.-M., Matyi, J., Lyketsos, C. G., Nowrangi, M. D., \& Rosenberg, P. B. (2020). Neuropsychiatric Symptoms As Risk Factors for Cognitive Decline in Clinically Normal Older Adults: The Cache County Study. The American Journal of Geriatric Psychiatry, 28(1), 64-71. https://doi.org/10.1016/j. jagp.2019.03.023

Camacho-Conde, J. A. (2009). Síndromes Geriátricos [Geriatric Syndromes]. Albay Ediciones S.L.

Camacho-Conde, J. A. (2019). Enfermedad de Parkinson: Implicaciones Autonómicas y Afectivas [Parkinson's Disease: Autonomic and Affective Implications]. Wanceulen.

Cerdá, R., López-Torres, J., Fernández, C., López, M., \& Otero, A. (1997). Depresión en Personas Ancianas. Factores Asociados [Depression in Elderly People. Associated Factors]. Atención Primaria, 19(1), 12-17.

Cosh, S., Helmer, C., Delcourt, C., Robins, T. G., \& Tully, P. J. (2019). Depression in Elderly Patients with Hearing Loss: Current Perspectives. Clinical Interventions in Aging, 14, 1471. http://doi.org/10.2147/CIA.S195824

Chan, C. K., Soldan, A., Pettigrew, C., Wang, M.-C., Wang, J., Albert, M. S., Rosenberg, P. B., \& BIOCARD Research Team. (2019). Depressive Symptoms in Relation to Clinical Symptom Onset of Mild Cognitive Impairment. International Psychogeriatrics, 31(4), 561-569. https://doi.org/10.1017/ S1041610218001138

Chou, K. L., \& Chi, I. (2004). Combined Effect of Vision and Hearing Impairment on Depression in Elderly Chinese. International Journal of Geriatric Psychiatry, 19(9), 825-832. https://doi.org/10.1002/gps.1174

Dean, K., Oulhaj, A., Zamboni, G., Dejager, C. A., \& Wilcock, G. K. (2014). Role of Depression in Predicting Time to Conversion to Mild Cognitive Impairment. The American Journal of Geriatric Psychiatry, 22(7), 727-734. https://doi.org/10.1016/j. jagp.2012.12.025

Dickinson, W. J., Potter, G. G., Hybels, C. F., McQuoid, D. R., \& Steffens, D. C. (2011). Change in Stress and Social Support as Predictors of Cognitive Decline in Older Adults With and Without Depression. International Journal of Geriatric Psychiatry, 26(12), 1267-1274. https://doi.org/10.1002/ gps. 2676

Diniz, B. S., Butters, M. A., Albert, S. M., Dew, M. A., \& Reynolds, C. F. (2013). Late-Life Depression and Risk of Vascular Dementia and Alzheimer's Disease: Systematic Review and Meta-aAnalysis of Community-Based Cohort Studies. The British Journal of Psychiatry, 202(5), 329-335. https://doi. org/10.1192/bjp.bp.112.118307

Ezzati, A., Katz, M. J., Derby, C. A., Zimmerman, M. E., \& Lipton, R. B. (2019). Depressive Symptoms Predict Incident Dementia in a Community Sample of Older Adults: Results From the Einstein Aging Study. Journal of Geriatric Psychiatry and Neurology, 32(2), 97-103. https://doi. org/10.1177/0891988718824036

Folstein, M. F., Folstein, S. E., \& McHugh, P. R. (1975). MiniMental State. A Practical Method for Grading the Cognitive State of Patients for the Clinician. Journal of Psychiatry Research, 12(3), 189-198. https://doi.org/10.1016/00223956(75)90026-6
Gallagher, D., \& Thompson, L. W. (1983.). Depression. In P. M. Lewinshon \& L. Teri (Eds.), Clinical Geropsychology: New Directions in Assessment and Treatment. Pergamon Press.

Garay, M. (2007). Relación entre Depresión y Deterioro Cognitivo [Postgraduate Thesis, Universidad Nacional de La Plata]. Repositorio Institucional de La UNLP. http://sedici.unlp.edu. ar/handle/10915/5482

Díaz, E. G. (2018). Prevalencia de depresión en el Adulto Mayor Institucionalizado [Undergraduate Thesis, Universidad de La Laguna]. https://riull.ull.es/xmlui/bitstream/handle/915/11024/ Prevalencia\%20de\%20depresion\%20en\%20el\%20adulto\%20 mayor\%20institucionalizado.pdf?sequence $=1$

Harrison, R., Savla, N., \& Kafetz, K. (1990). Dementia, Depression and Physical Disability in a London Borough: A Survey of Elderly People in and out of Residential Care and Implications for Future Developments. Age and Ageing, 19(2), 97-103. https://doi.org/10.1093/ageing/19.2.97

Izal, M., \& Montorio, I. (1993). Adaptation of the Geriatric Depression Scale in Spain: A Preliminary Study. Clinical Gerontologist, 13(2), 83-91. https://doi.org/10.1300/ J018v13n02 07

Jassim, H., Tuama, A. M., \& Alwan, H. (2019). Investigating of Geriatric Depression among Elderly in Nasiriyah City. Indian Journal of Public Health Research \& Development, 10(4). https://doi.org/10.5958/0976-5506.2019.00770.8

Javaherian, K., Newman, B. M., Weng, H., Hassenstab, J., Xiong, C., Coble, D., Fagab, A. M., Bezinger, T., \& Morris, J. C. (2019). Examining the Complicated Relationship Between Depressive Symptoms and Cognitive Impairment in Preclinical Alzheimer Disease. Alzheimer Disease \& Associated Disorders, 33(1), 15-20. https://doi.org/10.1097/WAD.0000000000000284

Jerez-Roig, J., Ferreira, L. M. d. B. M., Araujo, J. R. T., \& Lima, K. C. (2017). Functional decline in nursing home residents: A prognostic study. PloS One, 12(5), e0177353. https://doi. org/10.1371/journal.pone.0177353

Johansson, M., Stomrud, E., Lindberg, O., Westman, E., Johansson, P. M., van Westen, D., Mattsson, N., \& Hansson, O. (2020). Apathy and Anxiety are Early Markers of Alzheimer's Disease. Neurobiology of Aging, 85, 74-82. https://doi.org/10.1016/j. neurobiolaging.2019.10.008

Kim, H.-J., Kim, B.-H., \& Kim, O.-S. (2011). The Effect of Visual and Hearing Impairment on Depression and Cognitive Function in Community-Dwelling Elderly: The Korean Longitudinal Study of Aging 2008. Korean Journal of Adult Nursing, 23(6), 584-594.

Landi, F., Onder, G., Cesari, M., Barillaro, C., Lattanzio, F., Carbonin, P. U., \& Bernabei, R. (2004). Comorbidity and Social Factors Predicted Hospitalization in Frail Elderly Patients. Journal of Clinical Epidemiology, 57(8), 832-836. https://doi. org/10.1016/j.jclinepi.2004.01.013

Leung, M.-y., Wang, C., \& Wei, X. (2020). Structural Model for the Relationships Between Indoor Built Environment and Behaviors of Residents with Dementia in Care and Attention Homes. Building and Environment, 169, 106532. https://doi. org/10.1016/j.buildenv.2019.106532

Li, J. (2020). Elderly Suicide A Study on Suicide (pp. 181-213). Springer. https://doi.org/10.1007/978-981-13-9499-7

Lichtenberg, P. A., Ross, T., Millis, S. R., \& Manning, C. A. (1995). The Relationship Between Depression and Cognition in Older Adults: A Cross-Validation Study. The Journals of Gerontology Series B: Psychological Sciences and Social Sciences, 50(1), 25-32. https://doi.org/10.1093/ geronb/50B.1.P25

Lobo, A., Ezquerra, J., Gómez, F. B., Sala, J., \& Seva, A. D. (1979). Cognocitive Mini-Test (A Simple Practical Test to Detect Intellectual Changes in Medical Patients). Actas LusoEspanolas de Neurologia, Psiquiatria y Ciencias Afines, 7(3), 189-202. 
Loughrey, D. G., Pakhomov, S. V., \& Lawlor, B. A. (2020). Altered Verbal Fluency Processes in Older Adults with Age-Related Hearing Loss. Experimental Gerontology, 130, 110794. https:// doi.org/10.1016/j.exger.2019.110794

Llinás, J., Villalta, J., \& López-Pousa, S. (1991). CAMDEX. Adaptación y Validación Españolas. Áncora.

McDermott, L. M., \& Ebmeier, K. P. (2009). A Meta-Analysis of Depression Severity and Cognitive Function. Journal of Affective Disorders, 119(1-3), 1-8. https://doi.org/10.1016/j. jad.2009.04.022

Modrego, P. J., \& Ferrández, J. (2004). Depression in Patients with Mild Cognitive Impairment Increases the Risk of Developing Dementia of Alzheimer Type: A Prospective Cohort Study. Archives of Neurology, 61(8), 1290-1293. https://doi. org/10.1001/archneur.61.8.1290

Murphy, E. (1986). Affective disorders in the elderly: Churchill Livingstone.

Olivera, J., Benabarre, S., Lorente, T., Rodríguez, M., Pelegrín, C., Calvo, J. M., Leris, J. M., Idánez, D., \& Arnal, S. (2008). Prevalence of Psychiatric Symptoms and Mental Disorders Detected in Primary Care in an Elderly Spanish Population. The PSICOTARD Study: preliminary findings. International Journal of Geriatric Psychiatry: A Journal of the Psychiatry of Late Life and Allied Sciences, 23(9), 915-921. https://doi. org/10.1002/gps.2004

Panza, F., Frisardi, V., Capurso, C., D'Introno, A., Colacicco, A. M., Imbimbo, B. P., . . . Pilotto, A. (2010). Late-Life Depression, Mild Cognitive Impairment, and Dementia: Possible Continuum? The American Journal of Geriatric Psychiatry, 18(2), 98-116. https://doi.org/10.1097/JGP.0b013e3181b0fa13

Paterniti, S., Verdier-Taillefer, M.-H., Dufouil, C., \& Alpérovitch, A. (2002). Depressive Symptoms and Cognitive Decline in Elderly People: Longitudinal Study. The British Journal of Psychiatry, 181(5), 406-410. https://doi.org/10.1192/ bjp.181.5.406

Péquignot, R., Dufouil, C., Pérès, K., Artero, S., Tzourio, C., \& Empana, J. P. (2019). Depression Increases the Risk of Death Independently From Vascular Events in Elderly Individuals: The Three-City Study. Journal of the American Geriatrics Society, 67(3), 546-552. https://doi.org/10.1111/jgs.15731

Plati, M. C. F., Covre, P., Lukasova, K., \& Macedo, E. C. d. (2006). Depressive Symptoms and Cognitive Performance of the Elderly: Relationship Between Institutionalization and Activity Programs. Brazilian Journal of Psychiatry, 28(2), 118-121. https://doi.org/10.1590/S1516-44462006000200008

Prakash, A. (2019). Psychology of Depression in Elderly: A Review. EC Psychology and Psychiatry, 8, 263-272.

Rabbitt, P., Donlan, C., Watson, P., McInnes, L., \& Bent, N. (1995). Unique and Interactive Effects of Depression, Age, Socioeconomic Advantage, and Gender on Cognitive Performance of Normal Healthy Older People. Psychology and Aging, 10(3), 307-313. https://doi.org/10.1037/08827974.10.3.307

Ray, S., \& Agarwal, P. (2020). Depression and Anxiety in Parkinson Disease. Clinics in Geriatric Medicine, 36(1), 93-104. https:// doi.org/10.1016/j.cger.2019.09.012

Rodríguez, P. R. (1998). El Problema de la Dependencia en las Personas Mayores. Documentación Social, 112, 33-64.

Ruthirakuhan, M., Herrmann, N., Vieira, D., Gallagher, D., \& Lanctôt, K. L. (2019). The Roles of Apathy and Depression in Predicting Alzheimer Disease: A Longitudinal Analysis in Older Adults With Mild Cognitive Impairment. The American Journal of Geriatric Psychiatry, 27(8), 873-882. https://doi. org/10.1016/j.jagp.2019.02.003

Sánchez, I. (1999). Depresión, deterioro cognitivo y demencia: unas relaciones polémicas. Revista Española de. Geriatría y Gerontología, 34(3), 123-124.

Sakurai, R., \& Okubo, Y. (2020). Depression, Fear of Falling, Cognition and Falls. In M. Montero-Odasso, \& R. Camicioli
(Eds.), Falls and Cognition in Older Persons (pp. 49-66). Springer. https://doi.org/10.1007/978-3-030-24233-6

Schoevers, R., Beekman, A., Deeg, D., Jonker, C., \& Tilburg, W. v. (2003). Comorbidity and Risk-Patterns of Depression, Generalised Anxiety Disorder and Mixed Anxiety-Depression in Later Life: Results from the AMSTEL Study. International Journal of Geriatric Psychiatry, 18(11), 994-1001. https://doi. org/10.1002/gps.1001

Selbæk, G., Engedal, K., \& Bergh, S. (2013). The Prevalence and Course of Neuropsychiatric Symptoms in Nursing Home Patients With Dementia: A Systematic Review. Journal of the American Medical Directors Association, 14(3), 161-169. https://doi.org/10.1016/j.jamda.2012.09.027

Singh, M. K., \& Lee, A. G. (2019). Visual Loss and Depression. In H. Beaver, \& A. G. Lee (Eds.), Geriatric Ophthalmology (pp. 73-80). Springer. https://doi.org/10.1007/978-3-030-04019-2

Snowdon, J. (1990). The Prevalence of Depression in Old Age. International Journal of Geriatric Psychiatry, 5(3), 141-144. https://doi.org/10.1002/gps.930050302

Taivalantti, M., Barnett, J. H., Halt, A.-H., Koskela, J., Auvinen, J., Timonen, M., Järvelin M. R., \& Veijola, J. (2020). Depressive Symptoms as Predictors of Visual Memory Deficits in MiddleAge. Journal of Affective Disorders, 264, 29-34. https://doi. org/10.1016/j.jad.2019.11.125

Tan, E. Y., Köhler, S., Hamel, R. E., Muñoz-Sánchez, J. L., Verhey, F. R., \& Ramakers, I. H. (2019). Depressive Symptoms in Mild Cognitive Impairment and the Risk of Dementia: A Systematic Review and Comparative Meta-Analysis of Clinical and Community-Based Studies. Journal of Alzheimer's Disease, 67(4), 1319-1329. https://doi.org/10.3233/JAD-180513

Tarugu, J., Pavithra, R., Vinothchandar, S., Basu, A., Chaudhuri, S., \& John, K. (2019). Effectiveness of Structured Group Reminiscence Therapy in Decreasing the Feelings of Loneliness, Depressive Symptoms and Anxiety Among Inmates of a Residential Home for the Elderly in Chittoor District. International Journal of Community Medicine And Public Health, 6(2), 847-854. http://dx.doi.org/10.18203/23946040.ijcmph20190218

Valvanne, J., Juva, K., Erkinjuntti, T., \& Tilvis, R. (1996). Major Depression in the Elderly: A Population Study in Helsinki. International Psychogeriatrics, 8(3), 437-443. https://doi. org/10.1017/S1041610296002797

Wilson, R. S., Barnes, L., De Leon, C. M., Aggarwal, N., Schneider, J., Bach, J., Pilat, J., Beckett, L. A., Arnold, S. E., Evans, D., \& Bennett, D. A. (2002). Depressive Symptoms, Cognitive Decline, and Risk of AD in Older Persons. Neurology, 59(3), 364-370. https://doi.org/10.1212/WNL.59.3.364

Won, K.-A., \& Kim, J.-R. (2019). Effects of Cognitive-Health Improvement Group Program Combined with Lifestyle Education on Cognitive Function and Depression for the Elderly Korean People Using Rural Senior Center. Alzheimer's \& Dementia: The Journal of the Alzheimer's Association, 15(7), 1576-1577.

Wu, Y., Ma, Q., Sun, H.-P., Xu, Y., Niu, M.-E., \& Pan, C.-W. (2017). Myopia and Depressive Symptoms Among Older Chinese Adults. PloS One, 12(5), e0177613. https://doi.org/10.1371/ journal.pone.0177613

Yesavage, J. A., Brink, T. L., Rose, T. L., Lum, O., Huang, V., Adey, M., \& Leirer, V. O. (1982). Development and Validation of a Geriatric Depression Screening Scale: a Preliminary Report. Journal of Psychiatric Research, 17(1), 37-49.

Zunzunegui, M., Béland, F., Gornemann, I., \& Del Ser, T. (1999). La Depresión como Factor Predictor del Deterioro Cognitivo en las Personas Mayores. Revista Española de Geriatría y Gerontología, 34(3), 125-134.

Zunzunegui, M. V., Beland, F., Llacer, A., \& Leon, V. (1998). Gender Differences in Depressive Symptoms Among Spanish Elderly. Social Psychiatry and Psychiatric Epidemiology, 33(5), 195205. https://doi.org/10.1007/s001270050043 